\title{
AUTHOR INDEX VOLUME 4 (1986)
}

(The issue number is given in front of the page numbers)

Agrawal, S.P., National Social Science Documentation Centre (Short Communication)

(4) $323-328$

Armstrong, C.J. and J.A. Large, Employment criteria in the library and information sector: a British survey

Browne, M., Disciplinary study in information science: a foundation for the education of information professionals

(4) $305-318$

Clow, D. and C. Cochrane, User education and staff training in a continuing education programme

(1) $17-25$

Cochrane, C., see D. Clow

(1) $17-25$

Evans, G.E., Harmonization trends in American and Nordic library schools

(1) $3-15$

Fisher, W., Continuing education among special librarians

(3) $219-225$

Froehlich, T.J., Challenges to curriculum development in information science

(4) $265-289$

Hütteman, L., Information and documentation training at DSE (Short Communication)

(4) $319-322$

Jones, N., Learning in groups: strategies for effective group work in education and training for library management

(1) $27-45$

Large, J.A., see C.J. Armstrong

(3) $191-217$

Le Coadic, Y.F., Some reflections on present postgraduate education in information science (Short Communication)

(3) $227-228$

McGarry, K.J., Educational objectives and curriculum design: a case study of an undergraduate degree in librarianship and information science

(3) $165-190$

Moore, N., The library and information workforce in the United Kingdom

(2) 93-101

Nzotta, B.C., The staffing of African library schools

(4) 291-303

Shakir, S. and Tuck Cheong Wong, The curriculum of the School of Library and Information Science, Mara Institute of Technology, Malaysia: origins and development

(2) $103-117$

Wong, Tuck Cheong, see S. Shakir

(2) $103-117$

Wormell, I., Shaping future professional roles: New marketplace-oriented attitudes in curriculum development in Denmark

(2) $119-126$ 